65. Webster A, Scott GMS, Ridgway GL, Gruneberg RN. An outbreak of group A streptococcal skin infection: control by source isolation and teicoplanin therapy. Scand J Infect Dis 1987;19:205-209.

66. Hansen JL, Paulissen JP, Larson AL, et al. Nursing home outbreaks of invasive group A streptococcal infections-Illinois, Kansas, North Carolina, and Texas. MMWR 1990;39:577-579.

67. Mastro TD, Farley TA, Elliott JA, et al. An outbreak of surgicalwound infections due to group A streptococcus carried on the scalp. N Engl J Med 1990;323:968-972.

68. Burnett IA, Norman P. Streptococcus pyogenes: an outbreak on a burns unit. J Hosp Infect 1990;15:173-176.

69. Allen KD, Ridgway EJ. Streptococcus pyogenes: an outbreak on a burns unit. J Hosp Infect 1990;16:178-179.

70. Paul SM, Genese C, Spitalny K. Postoperative group A $\beta$ hemolytic streptococcus outbreak with the pathogen traced to a member of a healthcare worker's household. Infect Control Hosp Epidemiol 1990;11:643-646.

71. Harkness GA, Bentley DW, Mottley M, Lee J. Streptococcus pyogenes outbreak in a long-term care facility. Am J Infect Control 1992;20:142-148.

72. Auerbach SB, Schwartz B, Williams D, et al. Outbreak of invasive group A streptococcal infections in a nursing home. Arch Intern Med 1992;152:1017-1022.

73. Schwartz B, Ussery XT. Group A streptococcal outbreaks in nursing homes. Infect Control Hosp Epidemiol 1992;13:742-747.

74. Ridgway EJ, Allen KD. Clustering of Group A streptococcal infections on a burns unit: important lessons in outbreak management. J Hosp Infect 1993;25:173-182.

75. Simon PA, Chen RT, Elliott JA, Schwartz B. Outbreak of pyogenic abscesses after diphtheria and tetanus toxoids and pertussis vaccination. Pediatr Infect Dis J 1993;12:368-371.

76. Gordon G, Dale BAS, Lockhead D. An outbreak of group A haemolytic streptococcal puerperal sepsis spread by the communal use of bidets. Br J Obstet Gynaecol 1994;101:447-448.

77. Sarangi J, Rowsell R. A nursing home outbreak of group A streptococcal infection: case control study of environmental contamination. J Hosp Infect 1995;30:162-164.

78. Quinn RW, Hillman JW. An epidemic of streptococcal wound infections. Arch Environ Health 1965;11:28-33.

79. Dillon HC. Group A type 12 streptococcal infection in a newborn nursery. Am J Dis Child 1966;112:177-184.

80. Jewett JF, Reid DE, Sajon LE, Easterday CL. Childbed fever-a continuing entity. JAMA 1968;206:344-350.
81. Cayton HR, Morris CA. Injection site streptococcal abscesses in a clinic using disposable syringes. Monthly Bulletin of the Ministry of Health \& the Public Health Laboratory Service 1966;25:87-91.

82. Gezon HM, Schaberg MJ, Klein JO. Concurrent epidemics of Staphylococcus aureus and group A streptococcus disease in a newborn nursery-control with penicillin G and hexachlorophene bathing. Pediatrics 1973;51:383-390.

83. Peter G, Hazard J. Neonatal group A streptococcal disease. $J$ Pediatr 1975;87:454-455.

84. Dowsett EG, Herson RN, Maxted WR, Widdowson JP. Outbreak of idiopathic erysipelas in a psychiatric hospital. $\mathrm{Br}$ Med J 1975;1:500-502.

85. Greaves WL, Hinman AR, Facklam RR, Allman KC, Barrett CL, Stetler HC. Streptococcal abscesses following diphtheriatetanus toxoid-pertussis vaccination. Pediatr Infect Dis 1982;1:388-390.

86. McGregor J, Ott A, Villard M. An epidemic of 'childbed fever.' Am J Obstet Gynecol 1984;150:385-388.

87. Pritchard VG, Kerry CS. Streptococcal outbreak. J Gerontol Nurs 1988;14:19-23.

88. Schwartz B, Elliott JA, Butler JC, et al. Clusters of invasive group A streptococcal infections in family, hospital, and nursing home settings. Clin Infect Dis 1992;15:277-284.

89. Church DL, Bryant HE. Investigation of a Streptococcus viridans pseudobacteremia epidemic at a university teaching hospital. Infect Control Hosp Epidemiol 1989;10:416-421.

90. Teare EL, Smithson RD, Efstratiou A, Devenish WR, Noah ND. An outbreak of puerperal fever caused by group C streptococci. J Hosp Infect 1989;13:337-347.

91. Galloway A, Noel I, Efstratiou A, Saint E, White DR. An outbreak of group C streptococcal infection in a maternity unit. $J$ Hosp Infect 1994;28:31-37.

92. Haynes J, Anderson AW, Spence WN. An outbreak of puerperal fever caused by group G streptococci. J Hosp Infect 1987;9:120-125

93. DeNeef P. Role of rapid tests for streptococcal pharyngitis in hospital infection control. Am J Infect Control 1987;15:20-25.

94. Watanakunakorn C. Should routine throat cultures be done in hospital personnel complaining of a sore throat. Infect Control 1985;6:183-185.

95. Williams WW. Guideline for infection control in hospital personnel. Infect Control 1983;4:326-348.

\title{
More Links for the Epidemiologically Curious
}

\section{Edited by Murray D. Batt, MD; Charles E. Edmiston, PhD; John Heggers, PhD}

This month's list of interesting Web sites includes the AIDS Data Animation Project (www.ciesin.org/ datasets/cdcnci/cdc-nci.html). This site contains documentation of disease trends through still frames and animation for the years 1981 to 1993 . There are additional links to the National Center for Health Statistics and other collaborative sites and providers. The National Library of Medicine (NLM) (www.nlm.nih.gov) includes a vast database with access to online computer search vehicles (note: some of these resources will require a user ID password) and also includes a listing of NLM publications, research programs, and data on grants and contracts. There also is an interesting collection of Arabic and Persian documents on Islamic culture and the medical arts, which recently was updated.

On the international scene, Medistat, the Center for Medical Informatics and Biostatistics of the National Medical Institute at the National University of Singapore, has established a population-based data resource for Singapore and selected
Asian countries (http://biomed.nus. sg:80/MSTAT/welcome.html). This site, which is in the early phases of development, is intended to provide basic health indicators and statistics, health resource data, and population statistics for Asian nations. Finally, links to sites that have a focused interest in continuous quality improvement can be found at www2.umdnj. edu/gpph/ira18.htm. From this site, one can review CQI documents from the CDC-Prevention and Managed Care Program, Health Policy Institute, HRSA, and other programs. In addition, several additional links are provided to other nonprofit and commercial sites having an interest in this field. 